Historical Viewpoint:

\title{
The Neurology of Alice in Wonderland
}

\author{
T.J. MURRAY
}

SUMMARY: Charles Dodgson, better known as Lewis Carroll, author of the famous Alice stories, developed migraine and associated visual symptoms late in life. There has been considerable speculation that the bizarre phenomena and weird visual imaginery in Alice stories was directly related to the author's migraine.

This paper reviews several aspects of the character and health of Lewis Carroll including his shy, introspective personality, his stuttering and his attraction to young girls. It is concluded that there is no connection between the visual symptoms of migraine and the phenomena described in the Alice stories which were written over 25 years before the author developed migraine in his mid-fifties.

RÉSUMÉ: Charles Dodgson, mieux connu sous le nom de Lewis Carroll et auteur d'Alice au pays des merveilles, développa dans la cinquantaine des maux de tête du genre migraine et des symptômes visuels relatifs à ses migraines. On a souvent associé les bizarreries et les fantasmes des contes d'Alice aux migraines de l'auteur.

Cette anamnèse fournit des renseignements sur l'individualité et la santé de Lewis Carroll, y compris sur sa timidité, son caractère introverti, son bégaiement et son attrait envers les fillettes. On en a donc conclu qu'il n'y a aucun rapport entre les symptômes visuels relatifs à ses migraines et le phénomène décrit dans les contes d'Alice écrits 25 ans avant que l'auteur, alors cinquantenaire, développa ses migraines.

From the Department of Medicine (Neurology), Dalhousie University, Halifax, Nova Scotia.

Reprint Requests to: Dr. T.J. Murray, Head, Division of Neurology, Dalhousie University, 5849 University Avenue, Halifax, Nova Scotia, B3H $4 \mathrm{H} 7$.
On July 4, 1862 an unusual picnic took place. The Reverend Charles Dodgson, a thirty-year-old don at Oxford, took the three Liddell children, Ina, Alice, and Edith, for a row on the Isis River towards Godstow. As Dodgson was well known among children for his spontaneous and amusing stories, he began a narration. Robinson Duckworth, a second chaperone, later said that the story of Alice was composed as they rowed along for the benefit of little ten year old Alice Liddell. At the end of the day Alice said "Oh Mr. Dodgson, I wish that you would write out Alice's adventures for me!" The next day Dodgson made an outline and from then on continued to compose and illustrate the tale "Alice's Adventures in Wonderland". $\mathrm{He}$ completed an unillustrated version in 1863 and a beautifully handwritten, illustrated copy for Alice as an early Christmas present in November, 1864. When later published, the Alice stories became some of the most popular and most translated writings in the English language. Published under the pseudonym Lewis Carroll, the stories made their shy author famous, as well known today as in Victorian times.

\section{The Life and Health of Lewis Carroll \\ Charles Lutwidge Dodgson was} born in 1832, and educated at Rugby and Christ Church, Oxford. In 1861 he decided to become a minister and took deacons' orders, but shyness and stuttering prevented him from seeking the priesthood. He spent the rest of his life as a teacher of mathematics at Oxford, publishing some contributions on mathematics, logic and games.

Dodgson's mother and father were first cousins. He was the eldest son, the third of eleven children, most of whom stuttered. His father was a stern Archbishop but his mother was a very loving, warm person who showered a great deal of affection on young Charles.

Alice Liddell's son, Captain Hargreaves, described Dodgson in the New York Times as:

"this shy young man, rather tall, so straight he leaned over backwards with one shoulder higher than the other; thin and pale, with dark wavy hair that wanted cutting; rather goodlooking, despite incongruities of form movement - the young man with the 'two profiles', the crooked smile, the trembling upper lip, the housemaid's knee and jerky gait, the stammer, the highpitched voice, the low precise speech, the one deaf ear, but also with the blue eyes that held yours, and the change from a warm kindly glance to a suppressed twinkle, while the large white hands gripped yours with unexpected strength - it was to surprise a good many persons, including himself"

(Hargreaves, 1945).

He had a marked stutter and stammer that caused trembling of his upper lip. $\mathrm{He}$ had great difficulty giving sermons and seldom did so but when he did, they were composed in such a way that none of the words which caused him to stammer would appear. In 1897, in the last year of his life, he gave a long sermon lasting threequarters of an hour and later wrote in his diary "It has been the most formidable I've ever had to preach". Havelock Ellis (1945), in a study of British genius, wrote on thirteen eminent Englishmen, including Dodgson, Charles Lamb and Kingsley, all of whom stuttered, stating "There can be no doubt whatever as to the abnormal prevalence of stammering among British persons of ability". It is also of 
interest that the dodo in Alice in Wonderland represents Dodgson as the duck represents Duckworth. The dodo refers to his stuttering way of starting to pronounce his own last name.

There is some argument as to whether he was left-handed. In the Victorian Age left-handedness was not entirely respectable but his sister, Louisa, said he may possibly have been because she was. Certainly in his photographs he can be seen using a dominant right hand.

Dodgson as a child was not very healthy. His mother writes in her diary of a serious attack of whooping cough and says that he got over this quite well. Towards the end of his Rugby days he suffered from mumps. Already slightly deaf in the right ear, the mumps appeared to have caused further deterioration.

Dodgson was healthy most of his adult life, fond of exercise and long walks. He recorded in his diary a walk to Hastings, eighteen miles away, in five hours and twenty-five minutes, with an average pace of three and three-quarter miles per hour. In the last year of his life he acquired a Whiteley exerciser to develop his arm muscles. He liked to work hard and to retire physically fatigued.

He was prone to brief periods of mild depression, recurrent since his teens. Even at a young age he was writing poetry of solitude and despair. His poems at age 21 , when he was still seriously affected by his mother's death, are quite sad and depressing.

He often stayed awake late at night but did not complain of insomnia. He commented in one of his books on "sleepless nights", and when this was later interpreted by others as insomnia he corrected this in a later edition. He did invent a lot of games and mathematical puzzles for people to do in bed, intended in part to occupy the time and to keep one's mind on lofty and moral matters.

\section{Alice Analyzed}

The analyses of the Alice stories have been numerous (Goldschmidt, 1972; Greenacre, 1955; Grofjahn, 1947; Phillips, 1972; Schilder, 1938; Taylor, 1952) and range from suggestions that they are just playful non- sense, to Kenneth Burke's essay (1972) interpreting the acts and symbols largely as excremental images, to Shane Leslie's theory (1972) that they are reflexions on contemporary ecclesiastical history. Florence Becker Lennon (1945) felt that the stories represented unresolved Oedipal conflicts; Martin Grotjahn (1947) believed that Alice represented a symbolic equation for the phallus and her adventures were a return to the mother's womb. Geza Roheim (1972) felt that the Alice story was clearly one of oral trauma, with her manipulations of time, food, words and realities being highly schizophrenic. Goldschmidt (1972) suggested the whole story could be explained by "the desire for complete virility, conflicting with the desire for abnormal satisfaction".

The theories became "curiouser and curiouser". Goldschmidt (1972), and Schilder (1938) were intrigued by the tremendous amount of anxiety in Alice stories, even though Alice herself seemed aloof, and unperturbed by the anxiety and frenzy around her. Goldschmidt says that the anxiety is to a great extent related to eating or drinking and this represents oral aggressiveness and cruelty. This seems an over interpretation of the situation as Alice is controlled and calm in this bizarre world of unexpected frenzy. Heath (1974) noted that she took all the strangeness for granted, remained aloof, even snobbish, and did not see or appreciate the author's jokes.

Phyllis Greenacre (1955), in a very detailed study suggested that Dodgson really hated his mother but loved his father, a seeming contradiction to everything known about him. She believed that this explained the obvious mother symbols, with the Queen of Hearts and the Red Queen being heartless, cruel creatures while The King of Hearts and the White Knight are father symbols and very pleasant, kind fellows. She also argues that Alice herself is the major mother symbol, and feels that there is an unresolved and reversed Oedipus complex involved.

His pleasure in mirror writing and reversals has been related to his physical asymmetry and perhaps his lefthandedness. Goldschmidt adds the unusual suggestion that left and right dis- orientation and reversals are very often symbolizations for the inability to find a definite direction in one's sexuality, and for a wavering between the heteroand homosexual impulses. He feels that Dodgson creates a world without real love, that the absurd and cruel kings and queens in the stories were parental symbols and that the disagreeable animals around him represented his many brothers and sisters.

It is interesting to ponder what this quiet, reserved, shy deacon of the church would have felt had he read these theories. Dodgson himself maintained that his books meant nothing. However, he recognized that the words we use suggest more than we mean by them, so it is possible that the words of an author do represent more than even he planned.

Gardner (1960) in "The Annotated Alice" suggested that there was something preposterous about examining these books in academic detail. Chesterton (1960) also voiced his "dreadful fear" that the Alice story had already fallen into the heavy hands of scholars and was becoming "cold and monumental like a classical tune". Gardner (1960) excused himself by saying no joke was funny unless you see the point of it, and many of the most interesting things in Alice might only be understood if the times and habits of England and Oxford in the 1800 s were also understood. He also says that the children of today find Alice difficult to understand, and that the immortality of these books has continued, not because of children, but because adults, scientists and mathematicians in particular, seem to relish the stories. Heath (1974), in fact, suggests children are the least likely to understand them.

Fensch (1972) interpreted the stories as equivalent to the confused, surrealistic world of an LSD trip. Although his essay, "Lewis Carroll The First Acid Head", is unconvincing, there was a song by Grace Slick (1972) of the Jefferson Airplane called "White Rabbit" which again relates to the psychodelic nature of Alice's adventures and a suggestion that it is a drug experience. She repeats "Go ask Alice" which has been adopted as the title of a recent novel on teenage drug problems. 


\section{Migraine}

" 'I am very brave, usually.' He went on in a low voice: 'Only today I happen to have a headache'."

\section{Tweedle Dum}

Dodgson's name often appears on lists of famous migraineurs. $\mathrm{He}$ diagnosed his own migraine. It has been suggested that the visual phenomena that he had with migraine may have been responsible for the fantastic visual imagery, alteration of body image, and other bizarre phenomena in the Alice stories.

The first reference to migraine comes from the edited Dodgson diaries published by his nephew, S.D. Collingwood (1898). In 1888, at age fiftysix, he had his first episode which he described in his diary.

"This morning on getting up, I experienced a curious optical effect of 'seeing fortifications' - discussed in Dr. Lathan's book on 'bilious head-ache'. In this instance it affected the right eye only, at the outer edge and there was no head-ache."

Six months later it occurred in the left eye and a year later he had similar symptoms in association with an episode of synovitis of the knee. Altogether, about six episodes of migraine-like phenomena were noted in his diaries. Only vague references are made to headache and the clearest description is of recurrent visual experiences.

It would be unusual for classical migraine or typical migraine of any type to begin at age fifty-six. Dodgson wrote a detailed diary and there are accurate notes and interviews with people who knew him throughout his life, so it is likely that earlier episodes would have been recorded had they occurred. Unfortunately, he does not describe the characteristics of his headaches and the suspicion of migraine has always been based on the occurrence of visual fortification scintillations. Dodgson was well read in medical matters and he decided that the description of his visual phenomena fitted the pattern of "bilious headache", or migraine outlined in Dr. Latham's book.
It is conceivable that the visual phenomena he experienced in his fifties and sixties were due to transient cerebral ischemia. Visual phenomena of many forms can occur with vertebrobasilar ischemia, and headache occurs with both carotid and vertebrobasilar ischemia episodes. It is more likely however that the phenomena represent an unusual late onset of migraine as described by Miller Fisher (1980). Late onset migraine can resemble transient cerebral ischemic attacks. The neurological phenomena may be dramatic and prolonged with minimal or absent headache.

The suggestion that the visual imagery in the Alice stories may have been related to the author's migraine has appealed to many neurologists. Patients with migraine may perceive distortions in the size or shape of objects or, rarely, changes in their own body image or in the perception of people around them. Although this theory is interesting to contemplate as one reads the Alice stories, there is no convincing evidence to support it. Dodgson's initial migraine headache seems to have occurred about twenty-eight years after he first wrote the stories, and they appear to be just fanciful and imaginative story telling.

Unfortunately, he seldom consulted a physician so we do not have any confirmation of his diagnosis. In 1852 he did consult Edward Hamilton, an Edinburgh Phrenologist, who read his head bumps and gave an interesting report on the character of the client, although it did not bear on our question about his headaches (Hamilton 1954). The report ends on an interesting note: "As a medical man you could excel. Do not stress the brain too much at time (sic) because it is not firmly knit yet. Upon the whole a good head."

The phrenologist was accurate in noting Dodgson's strong love for children, his refinement, and his excellent logical mind. It has also been suggested that he probably could have been a good physician and he certainly had a great interest in medicine, keeping a large library of books on medicine, pathology, anatomy and other aspects of science. Along with telescopes, a microscope, mathematical instruments, geometrical solids and other items left at the time of his death, there was a human skull and a skeleton of a hand and foot. Although interested in medical science he had definite ideas about animal research and published a number of dissertations on the evils of vivisection, indicating that he did not accept the argument that animal experimentation was justified to relieve human suffering.

\section{Dodgson's Relationship with Young Girls}

Psychoanalysts have made much of his relationship with small girls. It is clear that this quiet, shy bachelor with a stern father and doting mother, had a life-long love for little girls, a disdain for small boys and an inability to relate to adult women. Because he had a hobby of photographing little girls in the nude and was the author of strange books about bizarre and complex creatures, he has been a frequent target for psychoanalysts. Many papers comment on the relationship to his mother, to Alice and to other small girls. Taylor (1952) makes two assumptions: that Dodgson was normal, although peculiarly retiring and secretive, and that his books had definite meanings, and were not merely "nonsense". Taylor suspects there was a great disappointment in his life which has been eliminated from the diaries and writings. He feels that Dodgson was in love with Alice and that the breakdown in that relationship was the great disappointment of his life. Although there was a long list of little girls in his life, none ever replaced his first love, Alice Liddell. Mrs. Liddell seemed to sense that there was something wrong in this relationship and began to discourage Dodgson's attention to her daughters. Later she seemed to regard him with some distaste, and burned all his early letters to Alice. There is a cryptic reference in Dodgson's diary on October 28, 1862 to his being out of Mrs. Liddell's good graces "ever since Lord Newry's business". The explanation behind Lord Newry's business remains a mystery to this day.

Some may question whether Dodgson loved Alice, which was likely, and whether he contemplated marriage with her, which was unlikely. Dodgson was twenty years older than Alice and she 
later married a gentleman by the name of Hargreaves. Dodgson himself later stated that he always remembered Alice as a child. He later wrote letters to Alice but always addressed them to "Dear Mrs. Hargreaves".

Isa Bowman, a little girl who played Alice on stage, was one of Dodgson's most favorite child-friends. One afternoon while walking hand-in-hand with her in Christ Church Meadows he explained how rivers flow downhill to the sea. The essence of the relationship seemed to be his ease and comfort with a small child, for the relaxed and happy interval was suddenly broken with the appearance of another university don. Carroll's ease in conversation and his relaxed manner disappeared and he was transformed back to the awkward, shy, stuttering Reverend Charles Ludwidge Dodgson. For the remainder of the walk the little girl said he "became difficult to understand and talked in a nervous and pre-occupied manner".

He thought the naked bodies of little girls, unlike those of little boys, to be extremely beautiful. With their mother's permission, he often sketched and photographed them in the nude. To prevent future embarrassment to the girls, he requested that after his death the pictures be destroyed or returned to the children or their parents. None of these photographs have survived. Although he was always careful to state that he would not in any way upset or disturb a child with his nude photography, and always obtained the permission from the mothers, there is some indication that the mothers were not always happy with him or his interest in their daughters. There is no suggestion however, that there was ever any impropriety. Unlike Humbert Humbert, the narrator of Vladimir Nabokov's novel, "Lolita", Carroll did not pursue young girls for any sexual pleasure, but rather because he felt sexually safe with them (Taylor 1952). Although he loved many young girls, there is no indication that he had any love relationship with an adult woman. $\mathrm{He}$ wrote some rather Victorian letters of passion to some young girls and this did not always please the mothers. In one instance he kissed a girl he thought to be fourteen, but who turned out to be seventeen. He wrote a mock apology to the mother but she replied sternly, "We shall see that it does not recur". It appears that Alice herself was not always happy with Carroll's attention and there was some antagonism towards him by the mother and sisters in the Liddell family.

He lost all fondness for these young women when they reached womanhood. He wrote, "About nine out of ten, I think, of my child-friendships get shipwrecked at the critical point 'where the stream and river meet', and the child-friends once so affectionate, become uninteresting acquaintances, whom I have no wish to set eyes on again."

\section{Later Life and Death}

In 1889 and 1890 he had a series of medical problems including a boil, synovitis in one knee, and later the other, ague, cystitis and lumbago, raising a question about Reiter's syndrome.

In 1891 he fell unconscious after morning chapel and awoke an hour later on the floor of the stalls, his nose bleeding. He reports, "It is the first time I fainted away. I sent for Dr. Brooks. I had some headache afterwards, but felt very little the worse."

He spent that Christmas at Christ Church and had further symptoms of joint pains and episodic visual disturbances. There are no more entries on his health, except to say that he was later feeling quite healthy and fit. At the New Year in 1897 he came down with flu and was too ill even to read the family prayers. During the next week he developed symptoms of pneumonia and asked his sisters to read a hymn which ended "thy will be done". On January 13 he said, "Take away these pillows - I shall need them no more". The next day he slipped into a coma and died. He was buried in the Guildford cemetery under a simple white cross with the name Charles Lutwidge Dodgson and below it the name Lewis Carroll.

Audrey Fuller, age fourteen, wrote a letter to the St. James Gazette suggesting that a fitting memorial for Lewis Carroll would be to raise money for a cot in the Children's Hospital at Great Ormond Street. Many letters from friends and supporters, including
Alice, assisted in this effort. At the Lewis Carroll Centenary in London in 1932 it was decided to initiate a more substantial memorial in the form of an entire children's ward at St. Mary's Hospital, Paddington. This was launched by a letter to the Times in March 1932 signed by Ramsey MacDonald, Stanley Baldwin, J.M. Barry, Alice Hargreaves, Walter De Le Mare, A.A. Milne and many others. The success of this appeal was partly due to the enthusiasm of Professor B.J. Collingwood, Professor of Physiology at St. Mary's Medical School, and a nephew of Dodgson. In Dodgson's Will he stated "Now that my nephew, Bertrum Collingwood, is studying for the medical profession, I should like him to have what he likes of the books on the subjects of anatomy, physiology, pathology and kindred subjects."

\section{Conclusion}

The self-diagnosed migraine of Charles Dodgson had it's onset at age 56 and was characterized mainly by visual symptoms. These visual symptoms were not the basis of the bizarre happenings in The Alice stories, as is sometimes suggested, since they were written over twenty-five years before his migraine began.

\section{BIBLIOGRAPHY}

BURKE, K., 1972. The Thinking of the Body. In: Aspects of Alice, pp. 340-343, ed. by Phillips, R., Victor Gollancz Ltd., London.

CHESTERTON, G.K., 1960. Quoted by Gardner M. In: The Annotated Alice. p. 7 , Clarkson N. Potter.

COLLINGWOOD, S.D., 1898. The Life and Letters of Lewis Carroll. p. 459, ed. by Collingwood S.D., T. Fisher Unwin London.

DODGSON, C.L., 1953. The Diaries of Lewis Carroll. Vol. 2. ed. by R.L. Green. Cassell, London.

ELLIS, H., 1945. Quoted by Lennon, F.B. In: Victoria Through the Looking Glass, p. 156, Simon and Schuster, New York.

FENSCH, T., 1972. Lewis Carroll - The First Acidhead. In: Aspects of Alice, pp. 421-424, ed. by Phillips, R., Victor Gollancz Ltd., London.

FISHER, M., 1980. Late-life Migraine Accompaniments as a Cause of Unexplained Transient Ischemic Attacks. Can. J. Neur. Sci. 7, 9-17. 
GARDNER, M., 1960. The Games and Puzzles of Lewis Carroll. Sci. Am. 202, 172 . 182.

GARDNER, M., 1960. The Annotated Alice. Clarkson N Potter. New York.

GARDNER, M., 1962. The Hunting of the Snark by Lewis Carroll. Annotated by Martin Gardner. Simon and Schuster, New York.

GOLDSCHMIDT, A.M.E., 1972. Alice in Wonderland Psychoanalyzed. In: Aspects of Alice, pp. 279-282, ed. by Phillips, R., Victor Gollancz Ltd., London.

GREENACRE, P., 1955. Swift and Carroll: A Psychoanalytic Study of Two Lives. International Universities Press, New York.

GROTJAHN, M., 1947. About the Symbolization of Alice's Adventures in Wonderland. Am. Imago. 4, 32-41.
HAMILTON, E., 1954. Quoted by Hudson D. In: Lewis Carroll, p. 67. Constable, New York.

HARGREAVES, C., 1945. Quoted in Lennon, F.B. Victoria Through the Looking Glass, p. 78, Simon and Schuster, New York.

HEATH, P., 1974. Introduction and Notes. In: The Philosopher's Alice. St. Martin's Press, New York.

LENNON, F.B., 1945. Victoria Through the Looking Glass: The Life of Lewis Carroll. Simon and Schuster, New York.

LESLIE, S., 1972. Lewis Carroll and the Oxford Movement. In: Aspects of Alice, pp. 340-343, ed. by Phillips, R., Victor Gollancz Ltd., London.
PHILLIPS, R., 1972. Aspects of Alice: Lewis Carroll's Dreamchild as seen Through the Critics Looking Glasses, Victor Gollancz Ltd., London.

ROHEIM, G., 1972. Further Insights. In: Aspects of Alice, pp. 332-339, ed. by Phillips, R., Victor Gollancz Ltd., London.

SCHILDER, P., 1938. Psychoanalytic Remarks on Alice in Wonderland and Lewis Carroll. J. Nerv. and Ment. Dis. 87, 159 168.

SLICK, G., 1972. White Rabbit. In: Aspects of Alice, pp. $419-420$, ed. by Phillips, R., Victor Gollancz Ltd., London.

TAYLOR, A.L., 1952. The White Knight; A Study of C.L. Dodgson (Lewis Carroll). Oliver and Boyd, Edinburgh. 